Western University Scholarship@Western

1994

\title{
Cotton Textile Prices and the Industrial Revolution
}

C Knick Harley

Follow this and additional works at: https://ir.lib.uwo.ca/economicsresrpt

Part of the Economics Commons

Citation of this paper:

Harley, C Knick. "Cotton Textile Prices and the Industrial Revolution." Department of Economics Research Reports, 9415. London, ON: Department of Economics, University of Western Ontario (1994). 


\title{
RESEARCH REPORT 9415
}

Cotton Textile Prices and the Industrial Revolution

by

\section{c. Knick Harley}

October 1994

\author{
Department of Economics \\ Social Science Centre \\ Un1versity of Western Ontar10 \\ London, Ontario, CANADA
}

N6A 5 C2 


\title{
Cotton Textile Prices and the Industrial Revolution
}

\author{
by \\ C. Knick Harley \\ Department of Economics \\ University of Western Ontario \\ London, Canada N6A 5C2
}

I would like to acknowledge the financial support of the Social Science and Humanities Council of Canada that made this research possible. I would also like to thank the staff of the John Ryland Library in Manchester and the Winterthur Museum in Wilmington for their assistance. 
Cotton textile prices, page 1

\section{Cotton Textile Prices and the Industrial Revolution}

Cotton textile technology defined the British 'Industrial Revolution.' Contemporaries and historians focused heroic or demonic explanations of economic change on the invention of spinning machines, the development of the factory system and the social consequences of the transformed cotton industry. The story of the inventors has long attracted attention but discussion of technological change remains incomplete. Technological change primarily effects a society by making goods cheaper. Even when the secondary social impact of technology brings about profound changes in work and social structure, change occurs because the new way of doing things is cheaper and more profitable. It is surprising, then, that we know little about how prices of cotton textiles changed between the 1760 s and the early nineteenth century. For example, Michael Edwards provide only sporadic information about cotton cloth prices in his The Growth of the British Cotton Trade, 1780-1815. Recently, Javier Cuenca Esteban, using partial information and various assumption, estimates that the price of cotton cloth price fell nearly a third between 1770 and 1801 and nearly a half more by 1815 . This implies that prices before the 'Industrial Revolution', were nearly three times their 1815 level, the intervening wartime inflation not withstanding. ${ }^{1}$ Better evidence shows, however, that he has greatly exaggerated the extent of the price decline.

Surprisingly readily accessible archival evidence exists from which accurate estimates of the price of many cotton goods can be constructed for the late eighteenth and early nineteenth century. The industry produced many different goods whose prices moved somewhat differently but we can confidently say that prices declined much less than Cuenca Esteban hypothesized. As qualitative discussions of the industry's technological change imply, prices of yarn fell more than the prices of finished cloth. The prices of fine yarns fell more than the price of coarse 
yarns. Coarse yarn (below 20 count), which dominated the pre-'Industrial Revolution' industry, fell little in price before 1800 and them declined by about a third to the end of the French Wars. Fine yarns (above 100 count) fell much more rapidly in the last decades of the eighteenth century, to a quarter or less of its previous price. Cloth prices, not surprisingly, declined less than yarn prices. Coarse cloth probably cost more in 1815 than it had in 1770 , the price of printing cloth comparable to that produced before the spinning inventions was roughly unchanged and the common post-war printing cloth declined in price to about three-quarters or two-thirds its pre-'Industrial Revolution' price.

The broad outlines of the 'Industrial Revolution' in the cotton industry are well known. Richard Arkwright's patent for roller spinning in 1769, or, perhaps more appropriately, the first production of yarn from his water-powered mill at Cromford in 1771 or 1772 where he perfected roller spinning and combined it with water-powered preparatory machinery, marked the start of dramatic change. Arkwright's machinery spun more homogeneous, stronger and finer thread than all but the most accomplished hand spinner could and, even initially, at considerable lower cost.

In 1779, Samuel Crompton perfected his mule, combining principals from the water-frame and Hargreaves' earlier jenny. The mule could spin finer yarns than Arkwright's water-frame and could produce both strong warp, or twist, and softer weft. Over the following decades both spinning technologies improved, but the most rapid improvements occurred in the mule which became the spinning machine of choice for most yarn. Increasingly experienced and skilled operators, spun finer and finer yarns on the mules. The water-frame, nonetheless, remained the machine of choice for spinning strong relatively coarse yarns. In the 1830s, Richard Roberts perfected the self-acting mule which eliminated most of the skill and strength needed for spinning coarse yarn and drove down its price. The finest yarns, however, could not 
by produced on the self acting mule and their production continued to demand skilled spinners working on semi-automatic mules.

Machinery quickly transformed yarn production in the last years of the eighteenth century, but had little effect on subsequent stages of cotton textile production. Yarn was woven or knitted and finished to produce the textiles sold to consumers. Mechanizing weaving proved much more difficult than spinning. Edmund Cartwright's 1787 machine was a mechanical but not economic success. Power loom weaving began effectively with William Horrocks' 1813 improvements. Even then hand production cost less than the power loom for all but simple fabric made of strong coarse yarn. The cotton industry continued to recruit new hand weavers until the 1830s. By the late 1830 s, however, the painful decline of hand loom weaving was clearly well begun.

Most yarn was woven but a considerable portion, particular finer yarn, was knit, principally into stockings. In the late sixteenth century, William Lee invented the stocking frame to knit hosiery, initially with silk. The machine spread to worsted in the seventeenth century and after 1730 to cotton, initially using imported Indian yarn. The machine embodied precise and complicated mechanical operations but was powered by the workman using it. During the eighteenth century, various inventors improved the frames but no technological breakthrough transformed the process as machinery transformed spinning. After mid century workers could knit fancy patterns on stocking frames. Late in the century, modifications allowed the frames to knit imitations of simple lace. In 1809 , John Heathcoat invented the bobbin net machine that revolutionizing lace production. Only in the middle of the nineteenth century did manufacturers adopt power and factory production. The stocking frame and the lace machine required fine, smooth, strong thread. Cotton threads for the machines were made by twisting two or more 
stands of cotton yarn together -- a process called "doubling." The yarn to double into the thread, therefore, needed to be particularly fine. The marked decline in the cost of fine yarn greatly benefitted both the stocking and lace industries. As the lace industry grew it demanded increasingly fine thread and in the years after the Napoleonic War most of the fine yarn spun by the cotton industry was doubled into thread for stockings, lace and sewing thread.

The products of both the loom and the knitting machines generally required further finishing although its extent varied considerably among products. Some simple fabrics were used as they came from the loom for lining, bagging and in some upholstery applications. Other woven fabrics, some stockings and some lace was sold white after simple bleaching. In other cases, the fabric was dyed or printed. Pile fabrics, like corduroy and velvet-like fabrics required extensive finishing to cut the treads woven into the cloth to create the pile and finish the surface. Fancy stockings and lace required embroidering. The costs of these operations, of course, varied greatly. Although some improvements occurred, particularly in bleaching and dying and in printing, in general finishing underwent only modest technological change during the 'Industrial Revolution.'

The cotton industry during the 'Industrial Revolution' was diverse; no single summary statistic can adequate represent the experience of the various different branches. The industry needs be understood within the context of different experiences in different branches and tracing the history of the prices of as wide a range of cotton goods as possible extends our quantitative knowledge. First, machinery cheapened yarn. Even here the diversity of experience was striking. Good evidence also exists on the price of grey cloth and simply finished white calicos. Unfortunately, much less information is available on more complex finishing processes, but the new sources provide some evidence on the cost of finishing. 
Cotton textile prices, page 5

\section{New Sources}

Two sets of surviving records in the Ryland Library in Manchester can considerably augment our limited knowledge on the economic effects of the 'Industrial Revolution' in cotton prior to the end of the Napoleonic Wars. Accounts of both Samuel Oldknow, a major calico, fustian and muslin manufacturer and later cotton spinner and Cardwell, Birley and Hornby manufacturers of printing cloth in Blackburn have survived and contain extensive price evidence. ${ }^{2}$ George Unwin partially exploited the Oldknow manuscripts in the 1920 s but he relied primarily on the letters among the papers (now at Columbia University in New York) and made only limited use of the accounts. The Cardwell, Birley and Hornby manuscripts are among a collection primary materials collected and deposited by A. P. Wadsworth.

The Cardwell, Birley and Hornby accounts, because they are consistent over many years, are the more useful for tracing the price effects of technological change, even though the Oldknow accounts are more extensive. The Cardwell accounts include detailed inventories that begin in 1768 and extend, with some breaks, to $1827 .{ }^{3}$ The inventories enumerate and value inventories of raw cotton; yarn identified by count and whether twist or weft; warps and yarn or cotton for weft in the hands of weavers; cloth identified as to type and whether bleached or not. Inventories survive for 1768,1769 and 1777 and then annual entries from 1781 to 1798. Unfortunately there is a 15 year break after which the series resumes in 1813. Yarn quotations can be matched reliably across the break since the system of classification did not change. Unfortunately, no such link can be made with the cloth inventories. Fortunately, however, the records contain enough detail to allow estimation of the price of the grey printing cloth whose price we know after 1812 .

The Oldknow manuscripts are extensive but most of the information is concentrated in 
the 1780s. Consequently they do not yield time series comparable to those in the Cardwell, Birley and Hormby accounts. Nonetheless they provide valuable conformation of the Cardwell data. In addition, they contain information to construct a second independent linking of late eighteenth century and nineteenth century cloth prices.

\section{Yarn Prices}

Arkwright's machine spinning factories that introduced the 'Industrial Revolution.' accomplished two things: they lowered the cost of making the types of cotton yarn that had been made and they introduced a new product -- fine English spun yarn. Cotton yarn was by no means homogeneous but different yarns were easily classified and we can follow the price histories of various yarns. Yarn was classified by two important characteristics. The first, "count" - the number of hanks of 840 yards that weighed a pound -- indicated the fineness of the yarn. The strength of the yarn, determined by twisting during spinning, provided the second important yarn characteristic. Greater twisting made yarn harder and stronger and suitable for use as the warp in weaving (the yarn placed in the loom into which the filling or weft is woven). This type of yam was referred as "warp" or "twist." A less highly twisted and consequently softer yarn was used for weft. Not surprisingly twist involved more extensive manufacturing and for a given count of twist cost more than weft.

By the end of the Napoleonic War, the mules of British fine spinning firms were able to spin yarn that rivalled the finest Indian yarn and, not surprisingly, impressed contemporaries who emphasized fine yarn in their discussions of the new industry. ${ }^{4}$ Modern historians have also concentrated on fine spinning, influenced both by contemporaries' lead and by the fact that the best surviving records in the industry are those of $\mathbf{M}^{\prime}$ Connel and Kennedy, one of the leading Manchester fine spinners. Consequently, the prices of fine yarn are the most readily available 
cotton good's prices. ${ }^{5}$ But fine yarn (of counts of 100 and above) were atypical of the industry. Most of this yarn was doubled into thread for stocking frames, lace machines and for sewing thread. A small amount was woven into the very finest muslims and some probably was used double in other high quality fabrics, but these fine yarns poorly represent the yarns woven into cloth either at the beginning or the end of the 'Industrial Revolution' and their price misrepresents the economic effect of the spinning machines. ${ }^{6}$

In 1760 s and 1770 s most yarns were below 20 count; toward the end of the century the average count was in the high twenties; by the 1830 it reached about $40 .^{7}$ Fortunately, the Ryland Library accounts contain prices of common coarse and medium yarns that went into most of the industry's cloth production. This information can be combined with some other sources to provide a clear picture of the course of price for yams of various fineness.

The Cardwell, Birley and Hornby inventories consistently contain data for coarse and medium count yarns. Initially, the firm wove with linen warps ('Irish"). Then in 1781 and 1782 "Arkwright twist" for warps is explicitly listed. Thereafter, several counts of weft and twists are listed. The classification of yarn by count and weft or warp was sufficiently standardized that the observations up to 1798 are probably directly comparable with the observations that resume in 1814. Yarn prices from the inventories are presented in Figure 1 and Appendix Table 1.

The Oldknow records complement and confirm the Cardwell inventories. One of the earliest documents in the Oldknow records is an inventory dated 11 August 1783. The inventory presents us with a cross section of prices of twist and weft for counts between the 20 s and the 80s. The prices by count are plotted in Figure 2 and presented in Appendix Table 2. ${ }^{8}$ In addition, it is possible to extract prices for twist of various counts at various dates from 1783 to 1812 from various delivery books, spinning accounts, printed lists and after 1805 accounts 
of the operation of the Oldknow spinning mill at Mellor. These data are presented in Appendix Table 3 which identifies the various sources. The Oldknow records also contain extensive accounts of payments to spinners for various counts between 1786 and 1789 but these defy summary. ${ }^{9}$

The Cardwell and Oldknow records present reliable information about the course of yarn prices for the period after 1781. Arkwright's patent effectively lapsed in 1781 when he failed in an attempt to prosecute for patent infringement. It seems unlikely that the price of machine spun yarn had fallen greatly in the few first years when production was covered by Arkwright's patent. Certainly, Arkwright and his partners accumulated fortunes in those years. Nonetheless, additional data would be helpful. The Cardwell inventories contain data for weft of counts from 13 to 28 for 1769 but earlier information remains hard to come by. The best earlier information on mid eighteenth century yarn prices comes from a manuscript written by John Wyatt in 1743 which Edward Baines, Jr. saw and reproduced in large part in 1835. Regarding the cost of yarn and spinning in Lancashire in the early $1740 \mathrm{~s} .{ }^{10}$ Wyatt concluded:

I apprehend it may reasonably be infer'd ... that the price of yarn of about 20 skein per lb. may be generally about $2 d$. per skein....The price of fine yarns seems ... unsettled. I found, among the spinners, that the price of 40 skein yarn varied from $4 \mathrm{~s}$. $2 \mathrm{~d}$. to $6 \mathrm{~s}$. 8d. per lb. spinning; and from about 50 ty's to 60 ty's, the price was from 8 s. to about 13s. And one spinner I found [Wiggan] that had 20s. 6d. per lb. for some, which reel'd to about 80 ty's.

Probably about two shillings for fine cotton wool should be added to the spinning costs for fine counts. Julia de Lacy Mann discussed this evidence and concluded that while 80's were probably uncommon in the 1740s "in later years such counts cannot have been very uncommon." 
Other published sources confirm and amplify the Cardwell yarn prices. Mr. Bannatyne's Encyclopedia Britannica article on "Cotton Manufacture" reported that Samuel Crompton told him that he undertook fine spinning on the invention of his machine, i.e. 1779 or 80 . Crompton stated that he received 14 shillings plus cotton for 40 count; 25 shillings for 60 count and 42 shillings for 80 count. ${ }^{12}$ This price for warp yarn is consistent with the information in the Ryland Library manuscripts. The Cardwell inventory valuations for cotton warps, however, indicate that price fell rapidly in the following years. In addition, N. von Tunzelmann found a manuscript by Patrick Colquhoun in the Baker Library at Harvard, that contained additional confirming yarn prices for the late 1770 s and 1780 s. The relevant prices are reproduced in Appendix Table 4 and used in Figure 1 to fill gaps in the Cardwell data. ${ }^{13}$

The manuscript series contain a serious gap from about the turn of the century to the last years of the wars. Fortunately a reliable published series largely bridges the gap. The series, that begins in 1802 , shows the average price and count of twist taken from the records of a spinning mill. It appeared in the extensive evidence that the Factory Commissioners collected about the cotton industry in 1833 and was "furnished by Samuel Greg \& Co., not from their own mills, but they can vouch for its accuracy. ${ }^{\text {n14 }}$ The average count of the twist varied slightly from year to year but until 1825 remained close to 25 . In order to create a consistent time series, the average value of twist sold can be adjusted, using contemporary information, to a constant 25 count. The adjusted prices are included in Figures 1 and 3 and reported in the Appendix Table 4.

The spinning innovations, particularly the mule, introduced the spinning of high count yarns to Britain. The longest series of readily available yarn prices have both been for fine yarn. In 1835 Edward Baines, Jr. presented the price of 100 count yarn from 1786 annually to 1806 
with later quotations. In addition, T. S. Ashton's "Some Statistics of the Industrial Revolution" included a series of prices from the M'Connel and Kennedy records for 100, 140 count mule yarn from 1795 to 1840 and, for 200 count beginning, somewhat sporadically in 1799 . These prices are presented in Figure 3 and Appendix Table 4.

Figures 1 and 3 summarize the course of yarn prices. Together the prices of wefts of 18 , 28 and 40 count and twist of 20,25, 40 and 100 count adequately show the movement of yam prices. Between the 1760s and the turn of the century, the price of low count wefts, although initially spun on wheels, then on jennies, and finally in factories, shows little trend (of course, the real price fell since general wartime inflation had set in) remaining between 2 and 3 shillings a pound. By the end of the war, machine spun weft had fallen to just under 2 shillings a pound. The price of intermediate count weft declined somewhat more sharply. The Cardwell inventories valued 28 count wefts at 4 shillings and 8 pence in 1769, in early 1780s it was worth about 4 shillings and about 3 shillings and 9 pence at the end of 1798. It then fell more dramatically, despite inflation, to under three shillings a pound at end of the war. The most dramatic decline in coarse yarn prices occurred in the post war years. As the secondary literature suggests, warp prices fell more than weft prices as a result of the spinning inventions. In 1781, Cardwell, Birley and Hornby valued 20 count warps, purchased from Arkwright, at 6 shillings and 2 pence a pound, about twice the cost of wefts. The price fell dramatically to about 3 shillings 6 pence by the end of the decade and then more slowly to about 2 shillings and 6 pence at the end of the war. 40 counts warps that Crompton indicated cost about 15 shillings at the end of the 1770s, were valued by Cardwell at 10 shillings and 8 pence a pound in $1782 .{ }^{15}$ They fell to between 6 and 7 shillings by the end of the 1780s as competition and additional the spinning improvements took effect. The decline in price continued to around 3 shillings a pound at war's 
Cotton textile prices, page 11

end. Most dramatically, 100 count yarn, which was unobtainable before the 1780 s, fell from some 38 shillings a pound or more to around 8 shillings a pound at the turn of the century. After its initial rapid decline, the fall in price of fine yarn continued, but no more rapidly than coarser yarn, to reach some 6 shillings at the end of the war.

\section{Cloth Prices: English Calicos}

Cotton spinning, revolutionized by the 'Industrial Revolution,' only produced an intermediate product. The industry's final products were extremely varied and, unlike yarn, defy any easy classification. Fortunately, the Ryland manuscripts provide information on the prices of the industry's most important cloth, "calico", a simple weave fabric made of yam from about 20 count to about 40 count. Calico was used grey as an input into printed cloth. When bleached it was used a shirting and sheeting. When woven with coloured threads in warp it was a simple striped cotton and when coloured threads were also used in the weft it was a check. There were certainly differences among calicos but all their prices moved in union. Of course, in constructing a time series for calico care must be taken to make sure that like fabrics are used throughout.

The Cardwell, Birley and Hornby inventories provide prices of several cloth, both grey and bleached, The series start before the spinning inventions with cloth woven with a linen warp. After 1780 the cloths quickly became all cotton. The pre-1800 inventories contain quotations for five types of cloth, all of which were suitable for printing and which were also sold as shirting or sheeting when bleached. The first is "Common" cloth made with a 13 count weft. This cloth, with a $4 / 4$ width appears in the inventories from 1768 to 1783 . A similar but narrower (3/4) cloth appears from 1793 to 1796 . The second cloth is "Fine" woven with 18 count weft and is present in all the inventories. The third, a "Superfine" made of 28 count weft is also 
continuously present in the pre 1798 inventories, although the original cloth was replaced by another with somewhat different dimensions. After 1789 two finer cloths appear. "No. 2" contained a 40 count weft and "No. 3," a 50 count weft. Prices of various cloths from the late 1760 to 1798 are shown in Figure 4 reported in Appendix Table 5. Coarse cottons cost more in the late 1790s than they had in the late 1760 s but the price of finer cloths had fallen.

Sales accounts, weaving accounts, and cost books in the Oldknow records provide extensive information about costs and prices for a bewildering variety of cloths in the 1780 s. Unfortunately the records do not cover a long enough period to provide evidence about price change over time. Nor can the data on the prices of the wide variety of cloths there is no way to use them to estimate any meaningful industry average. The most useful prices in the accounts are for several types of calicos. Oldknow's "Common" calico is a $7 / 8$ cloth with 18 count yarn; his "No. 3" appears to be a wider (9/8) version of the same cloth. The "No. 4" and "No. 5" were $9 / 8$ cloth probable woven with yarn of mid 20 s count; the "No. 6" appears to be woven with mid 40 count. Prices of these cloths from 1784 to 1789 are presented in Appendix Table 6. Oldknow's prices are for bleached cloth and probably of somewhat higher quality than the Cardwell cloths. They provide general confirmation to the validity of the Cardwell data.

Cloth prices become more abundant in the nineteenth century. The best time series comes from the paper that Alderman William Neild, of Manchester, read to the Statistical Society in $1861 .{ }^{16}$ In the paper Neild presented a consistent series (after some minor adjustment indicated in the paper) for a standard cotton printing cloth similar to the finer calicos in the late eighteenth century records. Neild's price data run from 1812 to 1860 and are presented in Appendix Table 7. Other shorter series of price quotations confirm the representativeness of Neild's series and scholars have used it widely to represent the price trend for basis cotton cloth. 
To obtain a price series for cloth that covers the 'Industrial Revolution' we need to link cloth prices in the late eighteenth century with those of the nineteenth. Fortunately, Alderman Neild defined the cloth he was referring to in detail. The Cardwell, Birley and Hornby and Oldknow accounts contain information to calculate of the price of a similar cloth in the late eighteenth century. The accounts contain extensive evidence about the count of yarn, weight, breadth and reed of various cloths and the costs of various stages of cloth production. Details of the calculations are provided in the Appendix. The Cardwell, Birley and Hornby accounts indicate that a 7/8, 72-reed, grey printing cloth similar to Alderman Neild's would have cost about 29 shillings in 1796 . This is below the price of 35 shillings and 6 pence $^{17}$ that Alderman Neild reported for the boom year of 1814 but above the prices that prevailed in the post-war slump.

A similar, completely independent, calculation from the Oldknow accounts yields a cloth price of 36s. 7d. for about 1783. This is some 28 percent above the 1796 Cardwell estimate. Cardwell's cloth also cost more in the early 1780s than in 1796 . Fine cloth cost 28 percent more in 1783 than it had in 1796 . The more relevant superfine cloth cost 48 percent more in 1782 than it did in 1796 (the fine cost 4 percent more in 1782 than in 1783). The divergence between the fine and superfine prices occurred almost entirely between 1782 valuation and the next appearance of the superfine cloth in the inventories in 1785 . The fine cloth cost 9 percent more in 1783 than in 1785 while the superfine was 25 percent more expensive. The divergence is not inconceivable in these years when Arkwright's patents lapsed and the mule was introduced. It is, however, surprising in light of the fact that 20 count and 27 count cotton twist fell by almost exactly the same percentage. The calculations from the Cardwell and the Oldknow accounts yield remarkably close estimates from two completely independently separate set of data. Together 
they provide us with reliable, if not quite exact, link between cotton cloth prices in the late eighteenth century and after the Napoleonic Wars.

The trend in calico prices from the 1780 seems fairly well established. The price of Cardwell's "fine" and "superfine" calicos fell from the early 1780 s to the late 1790 s. The "fine" cloth price fell by about twenty percent while the "superfine" falling somewhat more -- about thirty percent. Calculation using the Neild cloth specifications show a price decline of about twenty percent between 1783 and 1796 and a further fall of about ten percent -- about a thirty percent decline from 1783 -- to the average price in the five years centred on 1815.

\section{The Change from Linen to Cotton Warps}

"Blackburn greys" of the sort that Cardwell, Birley and Hornby produced were often, but not always, made with linen warps before Arkwright's twist became available. The cotton printing cloth in Cardwell inventories in 1768 and 1769 had linen warps (identified in the inventories as 'Irish"). In 1777, 1781, 1782 and 1783 "cottons" with linen warps are distinguished from "calicos" with cotton warps. Thereafter, only "calicos" and cotton yarns appear in the inventories.

In the conventional view, the British used linen warps because they could not spin cotton warps and produced an inferior cloth before Arkwright's water-frame produced a usable twist. ${ }^{18}$ The truth is more complex. Certainly, satisfactory cotton warp was expensive to spin. Also legislation encouraged, in fact had it been enforced, required, the use of linen warp in printing cloth. The well-known Calico Act of 1721 (7 Geo. I, c. 7) prohibited the sale or use of "any stuff make of cotton or mixed therewith which shall be printed or painted with any colour or colours, or any calico chequered or striped, or any calico stitched or flowered in foreign parts, with any colour or colours, or with coloured flowers made there...Muslins, neckcloths and 
fustians excepted." Following passage of the act, Lancashire manufacturers stretched the definition of fustian to their advantage to cover any "material made in Great Britain of linen yarn and cotton wool." The "Manchester Amendment" of 1736 (9 Geo. II, c.4) explicitly accepted that definition of fustians and confirmed the legality of printed fustians but not calicos. ${ }^{19}$

Was, then, linen warp inferior but forced on the industry by government regulation? Or was it inferior and chosen because cotton warp was more expensive? Or did linen warp produce a comparable product, and was abandoned when cotton spinning innovations made cotton warp cheaper than linen? Cloths have long been woven from mixtures of fibres and casual evidence suggest that mixed fabrics dominate today. The issue relative quality needs to be resolved because it influences how we should regard our price data. If linen warp made an inferior cloth, then the price of 'cotton' cloth in the late 1760s, with its linen warp, underestimates the early price of cotton cloth; if not, direct comparison is appropriate. The evidence does not permit an iron-clad answer to these questions but suggests that the cloth made with the linen warp was very similar to that made with cotton warp.

As early as the 1730 s, Norwich woollen manufacturers complained that "of late years a stuff made of linen yarn mixed with cotton and improperly called by the name of fustian had been invented, and great quantities made, which when printed cannot without great difficulty be distinguished from an Indian calico." The woollen manufacturers may have exaggerated in hope of outlawing the cloth but some twenty years we see "a piece of English chintz [which] could not be distinguished from an Indian chintz" presented to the Princess Royal. Furthermore, British goods, some with linen warps and some with cotton warps, competed successfully with Indian cottons in West Africa and the Plantations, although Julia de Lacy Mann concluded that "the negroes almost always preferred Indian cottons if they could get them." 20 
Qualitative evidence, although suggestive, is by no means conclusive. The relative prices of otherwise comparable cloths with linen and cotton warps best indicates contemporaries' relative evaluation. The Cardwell inventories for 1781 and 1782 contain prices for similar cloths with linen and cotton warp. In 1781, a "fine" white cotton cloth (i.e. linen warp) 28 yards long was priced at $41 \mathrm{~s} .8 \mathrm{~d}$. while a calico (i.e. all cotton) of the same description was priced at $47 \mathrm{~s}$. 4d. -- a 13.6 percent premium. In 1782 , the quotations show little or no premium: fine white cotton was 34s., calico, 35s.8d.; Superfine calico and superfine cotton (21 yds. 5/4) were both $40 \mathrm{~s}^{21}$ Merchants' accounts present a similar picture. Order books from the mid $1780 \mathrm{~s}$ of Wister and Company of Philadelphia contain orders of printed goods from Peel, Yates and Co. In July 1785 , calicos sold at a premium over cottons. Cotton prints sold at 1 shilling and 9 pence to 2 shillings a yard while the same patterns in calico sold at 2 shillings to 2 shillings and 6 pence. In February 1788, Wissart ordered "callicos or cottons" without specific distinctions and indicated the same price for both. ${ }^{22}$ Some 20 years later, in 1808 , Oldknow recorded in his notebook his response to a customer's enquiry. He offered a piece of cotton and flax shirting at 2 shillings and 6 pence a yard or a piece of all twist shirting cost some 20 percent less -- 2 shillings a yard. ${ }^{23}$ Prices indicate that consumers found the fabrics essentially identical. Producers therefore probably chose the warp on the basis of cost. Initially small amounts of pure cotton cloth could be sold at a small premium but that premium quickly disappeared. Later, satisfying a preference for mixed cloth required payment of a premium over all cotton cloth.

\section{v. Other Series of Cloth Prices}

Although a cotton industry existed in Europe before the various East India Companies began to import Indian cottons in the seventeenth century, Indian goods set the standard before the 'Industrial Revolution'. In his consideration of cotton cloth prices, Javier Cuenca Esteban 
presents important new series for cloth prices by calculating the annual average price per piece of Indian calicos and muslins sold in London by the East India Company. Unfortunately legislative restrictions may have caused divergence between the prices of Indian and British cloth. Because the 1721 Calico Act prohibited the sale or use in Britain of printed, striped or chequered Indian cottons, Indian calicos imported by the East India Company did not compete in the English market but were printed for export. After 1750, however, significant quantities of British striped, checked and printed cottons (both all cotton and cotton combined with linen) competed with Indian calicos reexported from London in Africa and the New World. This competition seems to have kept the prices of Indian and British goods close to one another. Certainly, the price trend in Indian calicos corresponds closely to the prices from the Ryland Library records (see Figure 5). The Indian calico prices probably provide a fairly accurate picture of price fluctuations in Britain during gap in English prices from 1799 to 1812.

The prices the East India Company realized for muslins, which could be sold in England, exhibits a surprising, but brief, spike in early 1780 s. On trend, abstracting from the early 1780 s peak, muslin prices declined more rapidly than calicos prices, reflecting the impact of the new spinning machines that rapidly cheapened the price of fine yarn in Britain. The sharp decline in muslin prices from the 1780s peak -- 1781 is usually cited as the start of English muslin production ${ }^{24}$-- seems to have misled many commentators on the 'Industrial Revolution.' Michael Edwards concluded from an 1788 East India Company spokesman's complaint that muslin price had fallen sharply since 1783 that "in the 1780 s there was a reduction in the price of cotton cloth. ${ }^{125}$ In fact, as we can see, a brief surge in muslin prices was reversed. The reversal of muslin prices probably also lay behind the earliest complaints of falling piece rates for hand-loom weaving that arose from the muslin branch. 
A series of price quotations also exists for a heavy fustian and shows modestly increasing prices between the third quarter of the eighteenth century and the first quarter of the nineteenth. The data, that Lord Beveridge extracted over fifty years ago by from the accounts of the Lord Chamberlain's Department, show the price paid for fustian for lining the watermen's breeches. ${ }^{26}$ The fustian was a heavy cloth, probably similar to today's blue jean, but bleached rather than dyed. It almost certainly was woven with a linen warp in the mid eighteenth century and became a completely cotton fabric sometime in the last quarter of the eighteenth century. ${ }^{27}$ The Lord Chamberlain's office bought on contracts and the price seldom changed, remaining at 12 pence per ell until 1783 , rising to 13 pence until 1797 when it rose again to 15 pence where it remained into the post war years. Certainly the series is unsuitable as an indicator of short run fluctuations, but the prices were market transactions and provide information about the long-run price trend in coarse fustian -- 'jean' and 'denim' -- which remains a staple of the industry.

\section{Weaving costs}

The nearly stable price of cotton grey cloth that the sources reveal appears to conflict with extensive evidence of distress among the hand-loom weavers that occasioned Parliamentary investigation as early as 1808 . Piece rates in muslin weaving undoubtedly declined sharply after the late 1790s. Various series show that the piece rate paid for weaving of fine cloth (Cambric) at the end of the war (average of 1814/6) was only about half the rate in the mid $1790 \mathrm{~s}^{28}$ Cuenca Esteban has made these rate an important part of his argument that cloth prices fell rapidly in the late eighteenth century.

The evidence must, however, be interpreted with care. First, all the early evidence comes from the small, fashion-dependent and high-paid muslin sector where cloth prices had 
temporarily been extremely high in the early 1780 s. Weaving technology changed little before the 1820 s so the weaving piece rates reflected the supply and demand for weavers. Cotton weaving expanded dramatically during the early expansion of the industry initiated by the spinning inventions. The English muslin branch emerged de novo in the early 1780 s in response to lower prices of fine yarn and high prices of Indian muslin. The expansion of the cotton industry following the spinning inventions created a golden age for the weavers. Almost all commentators have quoted from William Radcliffe's 1828 memoirs: ${ }^{29}$

In the year $1770, \ldots$ the father of a family would earn form eight shillings to half a guinea at his loom, and his sons, if he had one, or two, or three along side of him, six or eight shillings each per week....From the year 1770 to 1788 a complete change had gradually been effected in the spinning of yarns....[O]ur family and some others in the neighbourhood during the latter half of the time, earned from three to four fold wages [in weaving] to what the same family had heretofore done....The next fifteen years, viz. from 1788 to 1803 , which fifteen years I will call the golden age of this great trade, which has been ever since in a gradual decline....the price of labour only rose to five times the amount ever before experienced in this sub-division, every family bringing home weekly $40,60,80,100$ or even 120 shillings per week!!!

Most scholars conclude that Radcliffe's example was either atypical or exaggerated but agree that the introduction of the spinning machinery led to a marked increase in the piece rate of weavers. Piece rate for weaving muslins declined in 1790s and the first years of the nineteenth century as recruitment of new weavers brought the initial period of very high wages to an end and wartime closure of its export markets brought distress to the industry.

At the end of the Napoleonic Wars, ordinary weavers still earned more than they had 
before the spinning inventions. Wadsworth and Mann point out that in the mid eighteenth century ordinary weaving, if not the specialized weaving of some complex types of fustians and later of muslins, was a casual occupation that required little skill. ${ }^{30}$ They suggest that ordinary weavers grossed about six shillings a week around 1758. Arthur Young's informants during his northern tour in 1768 suggested earnings of seven or eight shillings a week for average weavers. ${ }^{31}$ John Lyons concludes in his study of the post-war decline of the hand-loom weaving that at the close of the Napoleonic Wars new weavers were still attracted to the industry by earnings of about 14 shillings a week. ${ }^{32}$ Weaving costs in 1815 appear to have been about twice what they had been in 1770 after more than a generation of dramatic ups and downs.

\section{Overall Assessment on Grey Cloth Prices}

The trends in grey cloth prices seem fairly well established (see Figures 4 and 5), although war induced fluctuations hamper their interpretation. It is difficult to disentangle trend and short-term fluctuations during the turbulent years from the resumption of war with France in 1803 to the return to normality around 1819 or $20 . .^{33}$ One view sees that technological change had lower prices quite significantly early in the century and that the post-Leipzig boom was an anomaly. It is probably better to emphasizes that war-time distress depressed prices, particular as the Berlin Decrees, the Orders in Council, the American Embargo and War disrupted exports. Prices rose to normal levels or above in the export boom after the allied victory at Leipzig late in 1813 only fall again in renewed distress caused by the post-war depression. Unfortunately, however, the period is so disturbed that the trend in prices cannot be accurately identified.

Fine cloth prices certainly declined more rapidly than coarse cloth prices. Coarse calicos made of yarn with counts in the 20s probably declined little on trend before 1800 and then may 
Cotton textile prices, page 21

have fallen ten or twenty percent, on trend until wars end. The most rapid decline in nominal price came in the post war years. Finer cloth declined somewhat in the 1780 s and 1790 s when fine yarn prices fell dramatically. Coarse fustians may even have increased in price during the war years.

\section{Finishing Costs}

Most of the cotton industry's final goods were more highly finished that the yarn and grey cloth whose price movements are documented above. Finishing, like weaving, changed much more slowly than spinning and so the prices of final products fell more slowly than those of yarn or grey cloth. Finishing costs varied considerably. Bleaching and finishing white cloth added little, dying somewhat more, printing of fashion chintz added more. The most expensive cloths were the pile fabrics the fustian branch produced.

We can roughly indicate the mix of products in the early post-war years. Yarn exports took a considerable portion -- between 20 and 30 percent -- of the yarn spun. Most of the finest yarn -- between seven and ten percent of the yarn spun by weight but forty percent or more by value added in spinning ${ }^{34}$ was doubled into thread and much of it sold to Midland hosiery and lace makers or exported. An additional twenty percent by weight of the yarn was exported in simple grey or bleached cloth. Domestic markets took a considerable but undocumentable amount of similar unfinished or simply bleached cloth for lining, upholstery, sheeting, shirting etc. The remaining third or so of the yarn became more complex fabrics for domestic and export markets. The products ranged from simple checks and stripes, where some dyed threads were woven into a simple cloth, to complex coloured muslin shawls, finely printed fashion goods and complexly finished pile fabrics like corduroy and velveret.

The most expensive finishing occurred not in the new calicos and muslins even when they 
were printed into chintz but in the old raised pile fustians. The fabrics were woven from stout yarn. In the 1830 s, the warp was commonly 32 count mule yarn doubled and twisted. The weft consisted of yarn of mid 20 s count. Earlier the yarns were probably somewhat coarser. The prices of these yarns, as we have seen, was only modestly reduced by the spinning inventions. Manufacturing a pile fabric -- the various cords, velverets, etc. -- involved several stages. First, the weaver incorporated extra filling yarns that floated over a number of warp yarns. After the cloth was removed from the loom, skilled fustian cutters cut the floating yarns by hand. Brushing then raised a pile from the cut yarns and the cloth was singed to produce a uniform surface. Typically the brushing and singing was repeated two or three times. The cloth was then dyed or printed. ${ }^{35}$ A 17 February 1787 letter from William Walton of Manchester to Lord Hawthsbury (later the first Earl of Liverpool), President of the Board of Trade, supporting the trade treaty with France details the costs of these stages in making a velveret. ${ }^{36}$ This document is sufficiently interesting to reproduce, slightly edited, in Table 1 below.

Calicos and muslins underwent much less elaborate finishing. Almost all the muslin exported was plain or white ${ }^{37}$ and the same was probably true of muslin for domestic sales. Much of the calico was also left white as shirting and sheeting, ${ }^{38}$ woven into checks or simply dyed. The late eighteenth century accounts provide considerable evidence as to the cost of this simple finishing. Bleaching costs were modest and changed little. ${ }^{39}$ Both the Cardwell and Oldknow accounts for the 1780 s and 1790 s show that bleaching added a shilling to grey cloth valued between 25 shillings and 30 shillings, say 4 percent. The cost fell somewhat with general prices in the post war years. In 1827, the Cardwell accounts list their No. 4 cloth in three categories. The first is 'grey' or 'printers' and is valued at 12 shillings a piece. The second is bleached and referred to as 'white goods' and 'shirting' and listed at 12 shillings and 8 pence. 
The final listing is 'shirting, finished, etc.' and is listed at 13 shillings. The inventory also

Table 1

Cost of a 36 Yard Printed Velverett

\begin{tabular}{|c|c|c|c|}
\hline & $f$ & $\mathbf{s}$ & d \\
\hline Cost of $20 \mathrm{lbs}$. of raw cotton to the Planter at $10 \mathrm{~d}$. per $\mathrm{lb}$. & & 16 & 8 \\
\hline Planter sell at $12 \mathrm{~d}$. to gain $2 \mathrm{~d}$. per $\mathrm{lb}$. & & 3 & 4 \\
\hline A Vessel brings it to England at $1 / 2 \mathrm{~d}$. per $\mathrm{lb}$. & & 2 & 6 \\
\hline Primage to the Master of the Vessel & & & 2 \\
\hline Charges at the Port for receiving and forwarding & & & 1 \\
\hline Expense of Navigation on land to Manchester & & & 10 \\
\hline Dealer charges on cotton & & 1 & 8 \\
\hline Paid to Spinner at $15 \mathrm{~d}$. per $\mathrm{lb}$. & 1 & 5 & \\
\hline Paid to Weaver at $15 \mathrm{~d}$. per $\mathrm{lb}$. & 1 & 5 & \\
\hline Paid to Dresser for dressing over a red hot iron & & 4 & \\
\hline Paid to the Cutter & & 10 & \\
\hline Paid to Scourer & & 2 & \\
\hline Paid to Printer for Printing 36 yds. at $6 \mathrm{~d}$. & & 18 & \\
\hline Paid for Penciling 36 yds. at $2 \mathrm{~d}$. & & 6 & \\
\hline Paid to Calendarman for finishing and making up & & 3 & \\
\hline to Warehouse Servant for superintendence & & 2 & 6 \\
\hline to a Proportion of the Expenses in travelling to sell & & 2 & 6 \\
\hline to the Manufacturer's Profit, $15 \%$ & & 15 & \\
\hline \multirow[t]{2}{*}{ to London, Bristol \&c. Merchants Profit $10 \%$} & & 10 & \\
\hline & 6 & 11 & 7 \\
\hline
\end{tabular}

The value of the different materials expended in the various operations performed on the ps. of velverett is about 
includes a 6/4 No. 2 cloth which is listed as 'finished Cambric' at 12 shillings and 4 pence and as a grey cloth at 11 shillings and 2 pence.

Much of the cotton cloth finished beyond bleaching appears to have been died in the yarn and woven into thin stripes or checks on a white background. ${ }^{40}$ The Cardwell inventories contain entries for dyed yarn that, when compared with the value of undyed yarn of the same count, indicate the cost of dying. Dying cost varied with the colour; about 1s. $6 \mathrm{~d}$. per pound for blue, green and brown and perhaps twice as much for red. A typical check or stripe cloth consisted predominantly of white background with a sixteenth to an eight of the yarn dyed. A four pound cloth contained perhaps half a pound of coloured yarn and dying increase its price of about five percent over simple bleached cloth. ${ }^{41}$ Dying finished cloth cost about the same per pound as dying yarn. Cloth worth 25 to 30 shillings weighted 4 to $5 \mathrm{lbs}$, , so dying the entire cloth would have increased its value by a quarter to a half.

Printing was a more expensive method of finishing. The 1787 velveret in Table 1 was printed and pencilled (a process of adding and colouring simple patterns by hand) at a cost of a third of the grey cloth price. S. D. Chapman suggests that most printing in Lancashire would have added a third to a half to the price of grey cloth. ${ }^{42}$ Only a modest proportion of the output was printed. Leading cotton printers estimated to a Parliamentary Select Committee on the Duties on Printed Cotton Goods in 1818 that about 5 percent of the cotton imported was printed for the home trade. The returns from the duties on printed goods show about twice as many printed goods were exported as consumed at home. ${ }^{43}$ By weight, printed calicos accounted for some fifteen percent of the yarn spun or thirty to forty percent of the cloth finished beyond bleaching. 
Cotton textile prices, page 25

The price trend in expensively finished fashion goods is extremely difficult to document since fashion fabric, by definition, changes from year to year. Recently, however, a remarkable scrapbook, kept from 1750 s to the 1810 s by Miss Barbara Jackson, an unmarried country gentlewoman, has come to light. It contains small squares of material used for gowns along with notes of their prices. In her introduction to the published reproduction of the album Natalie Rothstein of the Textile Division of the Victoria and Albert Museum notes that "the materials in the album are thus of high fashion, the visible evidence of style." Printed cottons are present from the 1760s. Rothstein concludes that "cottons printed with lively patterns in several colours -- the chintzes as defined by the Laboratory -- never came down in price." 44 


\section{Appendix: Estimation of the Price of Alderman Neild's cloth, 1796 and 1783}

Ryland Library archival data support two independent well-based comparisons of cloth prices prior to 1800 with those that prevailed after the Napoleonic Wars. The grey printing cloth whose prices between 1812 and 1860 Alderman William Neild, a leading cotton Manchester printer, presented in an 1861 paper to the Statistical Society, provides the basis for comparison. Neild's cloth is described in detail in John Lyons' 1977 doctoral dissertation:

A printing calico with the following characteristics: 29 yards finished length, 28 inches finished width, with 84 picks of weft yarn per inch, and 77 threads of warp yarn per inch. (note 5: In the finished cloth, warp threads are of a density of 77 to the inch, which results from the shrinkage due to tension from 30 inches in the reed at 72 threads per inch, to 28 inches in the woven state.) Each piece contained an average of 87696 picks of weft of 36 hanks to the pound and 2160 threads of warp yarn of 36 hanks to the pound. The weight of yam per piece is 2.215 pounds of warp, and 2.415 pounds of weft. The remainder of the 5 pounds 2 ounces of finished weight is flour used in dressing the warp preparatory to weaving. ${ }^{45}$

\section{1796: A cost estimate based on Cardwell, Birley and Hornby Inventories}

The Cardwell inventory for 1796 (Ryland Library, English Ms. 1199/2, 43-47) contains information about yarn and cotton in the hands of weavers which identifies cloths in progress and indicates the warps and weft or cotton for wefts supplied for their production. The wefts are identified by count and value. Since the inventories also contain valuations of warp and weft yarn by count, the weight of the weft and thus the tightness of the weave may be calculated. Unfortunately, less information is provided about the warps which are entered only by value. In some cases the reed of the warp is identified, but unfortunately the reed is not specified for 
Cotton textile prices, page 27

the most common fabrics. The inventories also contain valuations of the finished cloth from which it is possible to infer the costs of weaving each fabric.

The inventory data allow the calculation of the price of a cloth identical to Alderman Neild's. The yarn cost can be calculated simply. The inventory contains a price for no. 36 twist. The cost of a no. 36 weft does not appear in the accounts but may be estimated by interpolation between the prices of no. 28 and no. 40 weft in the inventories. Estimating no. 36 by interpolation may slightly overvalue the weft since price rose slightly more rapidly by count between no. 40 and no. 50 in the accounts than between no. 28 and no. 40 . Weaving costs are slightly more difficult to calculate since there is not an exact match with the Neild cloth. The firm did, however, produce a 74 reed $9 / 8$ cloth with a warp woven from 50 count cotton. Calculating the weight of the weft from the value of the weft given out to weavers and the cost of 50 count yarn indicates that $2 \mathrm{lbs}$ of yarn were used in a 21 yard long piece of cloth. This implies that the weft was woven about eighteen percent tighter than in the Neild cloth ( 99 picks to the inch rather than 84). The cloth was wider, at $9 / 8$, but shorter at 21 yards rather than 29 yards. All in all, the 11 shillings costs of weaving -- or more precisely, the difference between the value of the yarn and the value of the unfinished cloth -- must have been somewhat above those for Neild's cloth. The cloth area was probably a little smaller (but Oldknow's accounts suggest that $9 / 8$ cloth may have been $9 / 8$ when finished and $5 / 4$ in the loom rather than being somewhat smaller than its nominal width on the loom as Neild reveals to be the practice later) but more tightly woven. The Cardwell cloth involved weaving some 84,000 yards of weft rather than the 73,000 in Neild's cloth. In addition, the Cardwell cloth was broader and used a finer thread that required more care in weaving to avoid breakage. We will probably not underestimate the weaving cost if we make it proportional to the weight of weft woven, or 9 
shillings and 7 pence. The costs of a 7/8, 72-reed, grey printing cloth in 1796 can then be estimated as follows:

$\begin{array}{lr}\text { Raw cotton } & 8 / 6 \\ \text { Spinning: } & 6 / 9 \\ \text { warp } & 3 / 9 \\ \text { weft } & 9 / 7 \\ \text { Weaving (including warping) } & \\ \text { Total } & =28 / 7\end{array}$

\section{1783: A cost estimate based on Oldknow Records}

Oldknow's accounting records also support an estimate of a price for Neild's cloth. Important information appears in several different accounts that must be linked. The record for the calculation is a "Costing Book" (Ryland English Ms. 796 (1)) which contains detailed cost estimates for a large number of fabrics. The estimates appear to have been made at various dates and, unfortunately, only a single entry (The 10th page (marked 5), containing an estimate of a $4 / 4$ domestic 60 reed cloth is dated 30 July 1788. The most relevant cost accounts for comparison with Neild's cloth are calicos that appear before this page. In particular, there are estimates for various $9 / 8$ calicos that seems to correspond to the principal calicos mentioned in Oldknow's sales and weaving accounts. The sales accounts reveal that the mainstay of Oldknow's calico trade was a 9/8 calico referred to as 'No. 4.' The weaving accounts from 1784 to 1786 (Eng. Ms. 755) identify the width, reeds and count of weft for the various fabrics. The most common calico in these accounts is described as "72 reed, 5/4 calico" and the weft is 45 
count. The absence of $9 / 8$ width fabrics in the weaving accounts and of $5 / 4$ in the sales accounts suggests that both measures were actual widths of the same cloth at different stages. A cloth $5 / 4$ yards wide in the loom was ten percent smaller when complete.

The costing book (p. 4) estimate for a 72 reed, $9 / 8$ calico, 21 yards long was as follows:

\begin{tabular}{lr} 
Warp, 96 hanks No. 42 (2 lb. 6 oz) & $22 / 6$ \\
Weft, 2 lb. $12 \mathrm{oz}$, No. 45 @ 6/6 & $17 / 10$ \\
Sizing, Winding and Warping & $1 / 6$ \\
Weaving & $12 / 0$ \\
Bleaching and Finishing & $2 / 0$ \\
\hline & \\
Total & $32 / 4$
\end{tabular}

It is not possible to date this estimate exactly but Oldknow paid weavers 12 shillings a piece for 72 reed, $5 / 4$ calico in 1784,1785 and 1786 . The estimate cannot refer to 1788 (the date on the next page of the notebook) because then Oldknow paid his weavers only 8 shillings and 6 pence for weaving this fabric.

The Oldknow data can be used, like the Cardwell data, to estimate the cost of a cloth equivalent to Neild's for the early 1780 s. The costs of 36 warp and weft are available in the costing book (from the 64 reed 9/8 calico). I adjusted weaving cost because Oldknow's cloth is even more tightly woven Cardwell's. Neild's cloth used three hanks of warp yarn per yard of cloth; Cardwell, Birley and Hornby used 3.87 hanks per yard of about one third wider cloth and Oldknow used 5.7 hanks per yard. The Oldknow weaving records show that the cost of weaving a 4/4 plain muslin (using a count of yarn in the 70s) (Eng. Ms. 197 (II)) was proportional to the number of picks, or amount of yarn in the weft. Reducing Oldknow's weaving costs in 
proportion to the weft woven (100 hanks to 73 ) yields a weaving cost of 9 shillings. The cost of a Neild-type 72 reed, 7/8 grey printing cloth from Oldknow's accounts would be as follows:

Warp, 2.2 lbs. @ 6/8

Weft, 2.4 lbs. @ 4/9

(Cotton in warp and weft

Winding, warping and sizing

Weaving

Total
$14 / 8$

$11 / 5$

9/2)

$1 / 6$

$9 / 0$

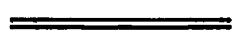

$36 / 7$ 
Cotton textile prices, page 31

Appendix Table 1: Yarn Pries (d. per lb.) Cardwell Inventories

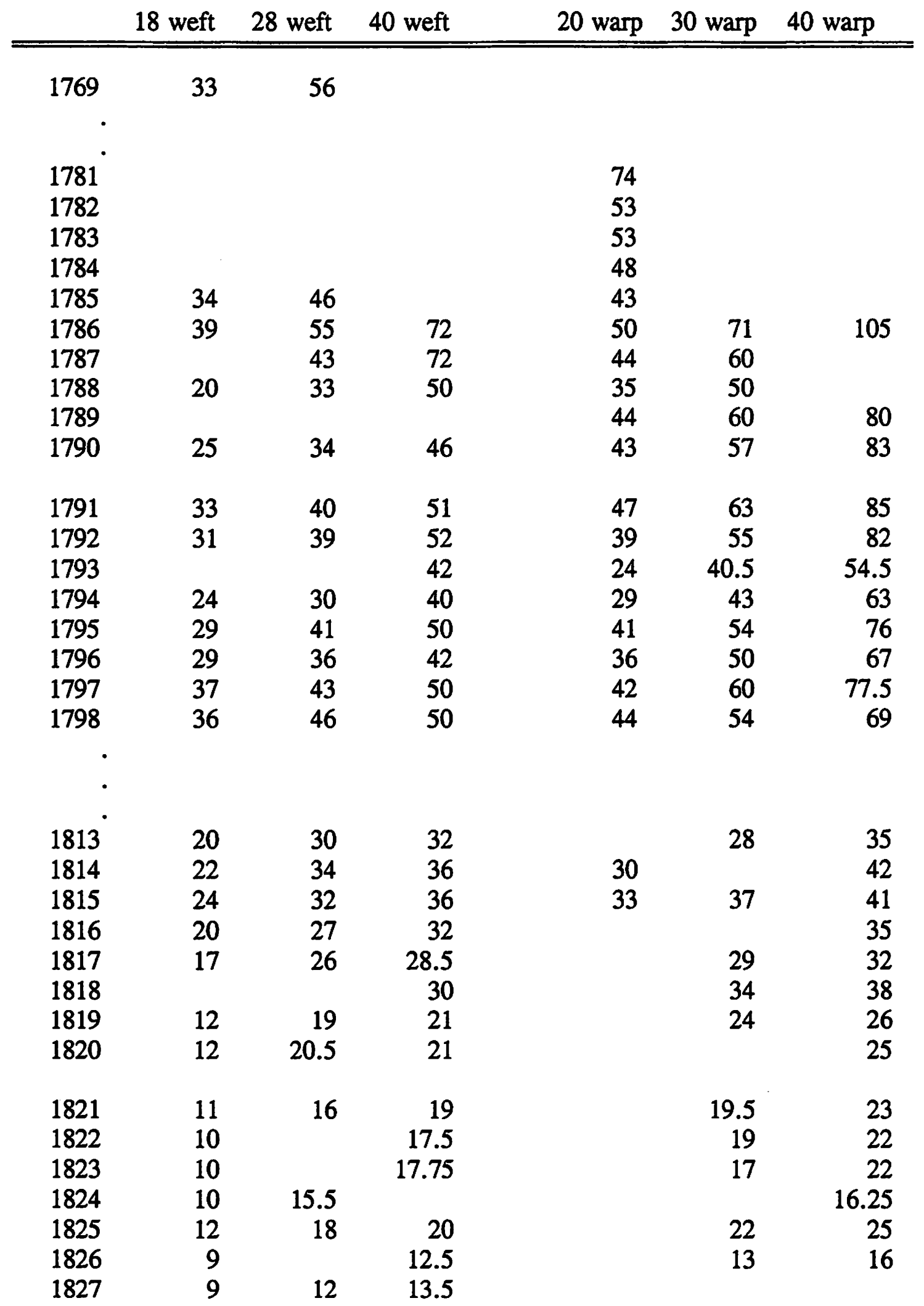


Appendix Table 2: Yarn Values (d, per lb.), by count and weft or warp, Oldknow's 1783 Inventory

\begin{tabular}{|c|c|c|c|c|c|}
\hline count & weft & warp & count & weft & warp \\
\hline 21 & & 45 & 55 & 119 & \\
\hline 22 & 46 & & 56 & & 247 \\
\hline 23 & & 60 & 57 & & \\
\hline 24 & & & 58 & & 267 \\
\hline 25 & & & 59 & & \\
\hline 26 & 54 & & 60 & & 210 \\
\hline 27 & & & 61 & 150 & \\
\hline 28 & 56 & 71 & 62 & 156 & \\
\hline $\begin{array}{l}29 \\
30\end{array}$ & & 77 & & & \\
\hline 31 & & & $66^{\circ}$ & 172 & 240 \\
\hline 32 & & 83 & . & & \\
\hline 33 & & 86 & & & \\
\hline 34 & & 90 & 70 & & 276 \\
\hline 35 & & & 71 & 210 & \\
\hline 36 & & 98 & 72 & 216 & \\
\hline 37 & & & & & \\
\hline 38 & & 108 & & & \\
\hline 39 & 72 & 117 & 80 & 264 & \\
\hline 40 & & 119 & 81 & & \\
\hline 41 & & 125 & 82 & 276 & \\
\hline 42 & & 131 & 83 & & \\
\hline 43 & & 137 & 84 & & 528 \\
\hline 44 & & & & & \\
\hline 45 & 88 & & & & \\
\hline • & & & 90 & & 600 \\
\hline & & & & & \\
\hline
\end{tabular}


Appendix Table 3: Oldknow's Twist Prices (d. per lb.)

\begin{tabular}{|c|c|c|c|c|c|c|c|}
\hline \multicolumn{7}{|c|}{ Count } & \multirow[t]{2}{*}{ Source: } \\
\hline & 20 & 30 & 40 & 50 & 60 & 80 & \\
\hline 1783 & 44 & 79 & 98 & & 210 & & Inventory, Eng. Ms. 744 \\
\hline 1790 & 35 & & & & & & Delivery Book, E.M. 802, 7-8 \\
\hline 1791 & 35 & & & & & & Delivery Book, E.M. 802, 32, \\
\hline 1792 & 46 & & 60 & 76 & 86 & 110 & Spinning Acct. E.M. 787, 9-11, \\
\hline 1793 & & 48 & 60 & 88 & 90 & 109 & Spinning Acct. E.M. 787 \\
\hline 1794 & & & 47.5 & 52.5 & 60 & 84 & Spinning Acct. E.M. $788,35-37$ \\
\hline 1797 & 55 & 65 & 77 & & & & Printed list, E.M. 826(20) \\
\hline 1798 & 59 & 65 & 77 & & & & Printed list, E.M. 826(21) \\
\hline 1805 & & 47 & & & & & Mellor Accts., E.M. 814 \\
\hline 1806 & 38 & & 45 & & & & Sales Acct., E.M. 790(3); 814 \\
\hline 1807 & & & 46 & & & & Mellor Accts., E.M. 814 \\
\hline 1811 & & 34 & 38 & & & & Mellor Accts., E.M. 824 \\
\hline 1812 & & & 35 & & & & Mellor Accts., E.M. 824 \\
\hline
\end{tabular}


Cotton textile prices, page 34

Appendix Table 4: Yarn Prices (d. per lb.), Various Sources

\begin{tabular}{|c|c|c|c|c|c|c|}
\hline & 18 weft & 40 weft & 25 warp & 40 warp & 100 twist & 100 twist \\
\hline $\begin{array}{l}1778 \\
1779 \\
1780\end{array}$ & 34 & $\begin{array}{l}74 \\
74\end{array}$ & & & & \\
\hline 1780 & 35 & 74 & & & & \\
\hline 1781 & & 87 & & & & \\
\hline 1782 & & 87 & 73 & 128 & & \\
\hline 1783 & & 77 & 64 & 119 & & \\
\hline 1784 & 32 & 75 & 55 & 119 & & \\
\hline 1785 & 34 & 70 & 54 & 117 & & \\
\hline 1786 & 36 & 62 & & & 456 & \\
\hline 1787 & 40 & 71 & 63 & 111 & 456 & \\
\hline 1788 & 34 & 57 & 49.5 & 82.5 & 420 & \\
\hline 1789 & & & & & 408 & \\
\hline 1790 & & & & & 360 & \\
\hline 1791 & & & & & 359 & \\
\hline 1792 & & & & & 169 & \\
\hline 1793 & & & & & 157 & \\
\hline 1794 & & & & & 157 & \\
\hline 1795 & & & & & 228 & 107 \\
\hline 1796 & & & & & 228 & 105 \\
\hline 1797 & & & & & 228 & 109 \\
\hline 1798 & & & & & 118 & 93 \\
\hline 1799 & & & & & 131 & 108 \\
\hline 1800 & & & & & 113 & 100 \\
\hline 1801 & & & & & 105 & 98 \\
\hline 1802 & & & & & 100 & 88 \\
\hline 1803 & & & 39 & & 100 & 85 \\
\hline 1804 & & & 39 & & 94 & 87 \\
\hline 1805 & & & 39 & & 94 & 100 \\
\hline 1806 & & & 36 & & 88 & 73 \\
\hline 1807 & & & 36 & & 85 & 76 \\
\hline 1808 & & & 38 & & 80 & 69 \\
\hline 1809 & & & 39.5 & & 80 & 71 \\
\hline 1810 & & & 42 & & 74 & 78 \\
\hline 1811 & & & 33 & & 56 & 54 \\
\hline 1812 & & & 30.5 & & 62 & 57 \\
\hline 1813 & & & 35 & & 72 & 68 \\
\hline 1814 & & & 45.5 & & 94 & 88 \\
\hline 1815 & & & 38.5 & & 86 & 79 \\
\hline
\end{tabular}


Cotton textile prices, page 35

Appendix Table 4: Continued

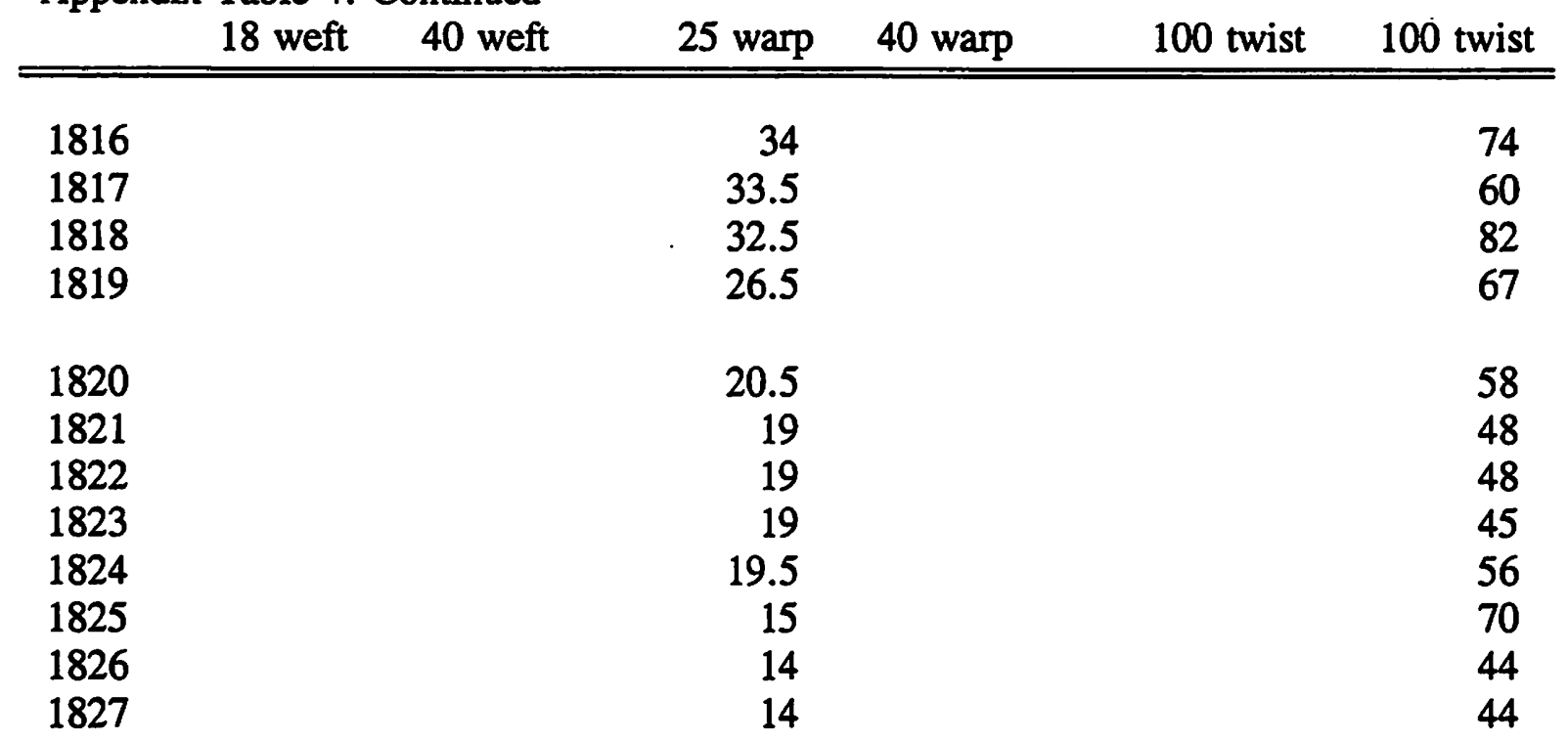

Sources: Col. 1-4, 1778-1788: N. von Tunzelmann, Steam Power, p. 181 quoting from an unpublished MS by Patrick Colquhoun.

Col. 3, 1803-1827: Report of the Factory Commissioners, PP, 1834, XIX, p. 185. The data are adjusted to correspond to a constant countof 25 on the basis of contemporary price quotations.

Col. 5: Baines, History, p. 357.

Col. 6: Lee, A Cotton Enterprise, p. 176. 
Appendix Table 5: Cardwell Cloth Prices (shillings per piece), 1768-1798

\begin{tabular}{|c|c|c|c|c|}
\hline "Common" & "Fine" & "Sup & & Fine Calicos \\
\hline $4 / 4 \quad 3 / 4$ & $4 / 4$ & $9 / 8$ & $5 / 4$ & No $2 \quad$ No \\
\hline $28 \mathrm{yds}$ & $28 \mathrm{yds}$ & $28 \mathrm{yds}$ & $21 \mathrm{yds}$ & \\
\hline
\end{tabular}

Cottons (i.e. linen warps)

\begin{tabular}{|c|c|c|c|c|c|c|}
\hline $\begin{array}{l}1768 \\
1769\end{array}$ & $\begin{array}{l}22.2 \\
23.3\end{array}$ & $\begin{array}{l}29.3 \\
29.5\end{array}$ & $\begin{array}{l}41.5 \\
41.5\end{array}$ & & & \\
\hline 1777 & 26.0 & 32.8 & 41.7 & & & \\
\hline 1781 & 35.0 & 41.7 & 48.7 & & & \\
\hline 1782 & 28.0 & 34.0 & 42.5 & 40.0 & & \\
\hline \multicolumn{7}{|c|}{ Calicos (i.e. cotton warps) } \\
\hline 1781 & & 47.3 & & & & \\
\hline 1782 & & 35.7 & & 40.0 & & \\
\hline 1783 & & 32.8 & & & & \\
\hline 1784 & & 31.0 & & & & \\
\hline 1785 & & 31.3 & & 32.0 & & \\
\hline 1786 & & 34.5 & & 35.0 & & \\
\hline 1787 & & 30.0 & & 30.0 & & \\
\hline 1788 & & 25.0 & & 25.0 & & \\
\hline 1789 & & 26.5 & & 27.0 & 33.0 & 40.5 \\
\hline 1790 & & 25.2 & & 27.0 & 33.0 & \\
\hline 1791 & & 30.8 & & 31.8 & 36.5 & \\
\hline 1792 & & 27.5 & & 29.5 & 35.0 & \\
\hline 1793 & 15.0 & 20.0 & & 21.0 & 25.0 & 27.5 \\
\hline 1794 & 18.5 & 23.0 & & 24.0 & 29.0 & \\
\hline 1795 & 23.5 & 28.5 & & 30.5 & 33.5 & 43.0 \\
\hline 1796 & 22.0 & 25.5 & & 27.0 & 31.5 & 36.0 \\
\hline 1797 & & 31.0 & & 30.5 & 31.5 & 34.5 \\
\hline 1798 & & 30.0 & & 30.0 & 32.0 & 34.0 \\
\hline
\end{tabular}


Appendix Table 6: Oldknow Calico Prices, 1784-9, pence per yard

\begin{tabular}{rrrrr} 
& $9 / 8$ No. 3 & $9 / 8$ No. 4 & $9 / 8$ No. 5 & $9 / 8$ No. 6 \\
\hline \hline & & & & \\
1784 & 22 & 27 & 32 & 42 \\
1786 & & 27 & & \\
1787 & 19 & 25 & 29 \\
1788 & & $191 / 2$ & 22 & 26 \\
1789 & & 19 & 29 \\
\hline
\end{tabular}

Sources: $\quad$ 1784: Eng. Ms. 774, Sales to Salte, 7 May. 1786: Eng. Ms. 775, Sales to Salte, 7 June.

1787: Eng. Ms. 775, Sales to Salte, 5 June.

1788: Eng. Ms. 776, Sales to Salte, 26 May.

1789: Eng. Ms. 777, Sales to Salte, 19 Dec, to Graves, Hodgson \& Co. 22 Dec. 


\begin{tabular}{|c|c|c|c|}
\hline \multicolumn{4}{|c|}{$\begin{array}{l}\text { Appendix Table 7: Cloth Prices, 1783, 1796, 1812-1827 } \\
\text { (shillings per piece) } \\
\text { Cardwell }\end{array}$} \\
\hline & No 3 & No 4 & Neild \\
\hline 1783 & & & [36.6] \\
\hline 1796 & & & {$[29.0]$} \\
\hline 1812 & & & 22.6 \\
\hline 1813 & 22.8 & 24.7 & 22.6 \\
\hline 1814 & 27.5 & 30.3 & 35.3 \\
\hline 1815 & 23.7 & 26.2 & 25.3 \\
\hline 1816 & 20.0 & 22.3 & 26.2 \\
\hline 1817 & 19.0 & 20.8 & 21.3 \\
\hline 1818 & 19.5 & 22.7 & 21.8 \\
\hline 1819 & 15.8 & 17.8 & 14.3 \\
\hline 1820 & 15.3 & 17.3 & 15.8 \\
\hline 1821 & 14.8 & 17.1 & 15.3 \\
\hline 1822 & 12.8 & 15.0 & 14.5 \\
\hline 1823 & 12.6 & 15.0 & 14.0 \\
\hline 1824 & 12.8 & 14.3 & 14.5 \\
\hline 1825 & 13.8 & 16.0 & 11.5 \\
\hline 1826 & 9.9 & 11.5 & 10.5 \\
\hline 1827 & 10.8 & 12.0 & 10.0 \\
\hline
\end{tabular}




\section{Endnotes}

1. Cuenca Esteban, 'British Textile Prices, 1770-1831.'

2. The Oldknow records are English Manuscripts 751-840. The Cardwell records are English Manuscripts, 1199/1- 3. The name of the Cardwell firm changes from time to time. I shall refer to them Cardwell, Birley and Hornby or just Cardwell in the text despite the actual name at the date of the relevant inventory.

3. The inventories seem to have survived because the bound volumes in which they were recorded also contains partnership contracts. Inventories continue for some years after 1828 but do not contain detail on commodities and prices.

4. Baines, History, p. 59-60, 201; Ure, Cotton Manufacture, i, 294; ii, 398.

5. Ashton, 'Statistics'; Lee, A Cotton Enterprise; Huberman, 'Labor Markets'.

6. Edwards, Cotton Trade, p. 254 reproduces Baines 100s and states "There is no detailed information about yarn prices before 1786."

7. Wadsworth and Mann, Cotton Trade, pp. 273-77; von Tunzelmann, Steam Power, p. 182; Huberman, 'Labor Markets'.

8. The data suggests two different types in different parcels of twist of counts from the mid 50s to the low 70s.

9. English Manuscripts, 750 and 760.

10. Baines, History, pp. $129 \mathrm{ff}$. The quotation is from p. 132. Wadsworth and Mann, Cotton Trade, 173-77 endorse this information.

11. Wadsworth and Mann, Cotton Trade, p. 177.

12. Baines, History, p. 200.

13. von Tunzelmann, Steam Power, p. 181. The warp prices included in the table for 1810 and 1816 are certainly misleading. They both come from secondary sources relating to manufacturers whose principal interest was in stocking and lace manufacture and the prices appear to relate to doubled thread. The cost of doubled thread of, say 25 count, would slightly exceed the cost of the pound of 50 count yarn from which it was doubled.

14. Parliamentary Papers 1834, XIX, p. 185.

15. The early quotations are from the Colquhoun data presented by von Tunzelmann.

16. 'An Account' of the Prices of Printing Cloth and Upland Cotton, from 1812 to 186, \&c."

17. Corrected for the difference between the cloth Neild reported in his first years and the cloth that made up the bulk of his series. 
18. I cannot resist repeating the observation made over sixty years ago by Wadsworth and Mann, Cotton Trade, (p. 111) since it remains nearly as true today as it was when they wrote. "Until recently, it was customary for historians to assert that, before Arkwright's machinery produced a twist strong enough for warps, pure cotton goods were not made in England. This is now known to be an error, but, though it is admitted that cotton warps were employed before 1770 , the extent of their use has perhaps hardly been realized."

See Joel Mokyr's misleading discussion of cotton technology during the Industrial Revolution in Lever of Riches, p. 96-99. There can be no doubt that the British were capable of producing a cotton warp (Wadsworth and Mann, Cotton Trade, p. 175-7; Montgomery, 'John Holker'. For conditions at time of Arkwright's invention and the repeal of Calico Act at Arkwright's initiative see Fitton, Arkwrights, p. 33. Arkwright's main complaint was over duty of 12 Anne, c. 9 (Wadsworth and Mann, Cotton Trade, p. 133, 484-5).

19. Wadsworth and Mann, Cotton Trade, p. 140 also O'Brien, et al, 'Political Components', pp. 408-10.

20. For the African trade see Wadsworth and Mann, Cotton Trade, pp. 148-161. For printed cottons in England see Baines, History, p.261-2. and Wadsworth and Mann, Cotton Trade, p. $139-41$.

21. The 1777 inventory includes calicos but without complete identification valued at $40 \mathrm{~s} .6 \mathrm{~d}$. These probably correspond to the fine cotton valued at $32 \mathrm{~s}$. 10d. -- a slightly higher premium than in 1781.

22. Wister Family Order Books, Winterthur Museum, MS 56 x 10, p. 19 and 167.

23. English Ms. 829, p. 26.

24. Anderson, Origin of Commerce, 1801, p. 655.

25. Cotton Trade, pp. 239-40.

26. Prices, pp. $450,458$.

27. Arthur Young visited Manchester on his Northern Tour in the summer of 1768 and was given extensive information about the industry. He listed thirteen types of fustians which he reported "are worked up of cotton alone, of flax and cotton, and of Hamborough yarn." North of England, Vol. III Letter XX p. 242.

28. Bythell, Handloom Weavers, p. 99, 275; Cuenca Esteban, 'textile prices', p. 92.

29. Radcliffe, Origins, p. 59-66. Also see Baines, History, p. 337.

30. Cotton Trade, pp. 333-35.

31. North of England, Vol. III, Letter XX, pp. 243-247.

32. 'Cotton Industry', p. 36. 
33. See Crouzet, $L^{\prime} E c o n o m i e ~ B r i t a n n i q u e$ for description of the impact of the Napoleonic Wars on the British economy generally and the cotton industry specifically.

34. Calculated from Huberman, 'Labor Markets', p. 106 and 116, assuming average 140 count for Sea Island cotton and 30 average count for rest.

35. Ure, Cotton Manufacture, ii, 254-64; Atkin, pp. 158-64. Examples of 'Industrial Revolution' fustians may be seen in sample books in the Winterthur Museum (Ms. 65 x 698-700; 77 x 110).

36. BM Add.Ms. 38,376. Both Edwards, Cotton Trade, p. 240 and Cuenca Esteban, 'Textile prices', p. 83 report the cost shares in this document. Neither seems to have realized how atypical the finishing costs of a velveret were.

37. PP 1819 XVI, pp. 96-99. In the years 1814-16 81 million yards of 84 million yards of muslin exported were white.

38. Cardwell inventories 1827 lists bleached cloths as "shirting" and "sheeting."

39. Also see Alastair Durie, 'Textile Finishing,' p. 12 which shows no trend in the cost of bleaching (of linen cloth) from 1750 s to the 1830s.

40. Calico printers testifying to the 1818 Select Committee on the Duties on Printed Cotton Goods explicitly complained of competition with "white cambrics, white muslins, and other goods coloured in the loom, in imitation of printed cottons." (p. 5 also see pp. 7, 16, 20-21, 356).

41. See Oldknow Costing Book Eng. Ms. 796 (1). Small samples of Oldknow checks are preserved in Eng. Ms. 827.

42. Chapman and Chassagne, European textile printers, pp. 216-7.

43. See the S. C. on the Duties on Printed Cotton, pp. 5-6; 16. Baines, History, p. 283 presents data on the yards of cotton cloth printed for export and domestic use. The figures in the text are arrived at by assuming five yards of printed cottons used a pound of yarn.

44. Barbara Johnson's Album, p. 21

45. 'Lancashire Cotton Industry', p. 195. In fact Neild's price quotations for 1812 to 1817 were for a slightly finer cloth, an 80 reed rather than a 72 reed cloth. Neild stated that it would have sold for a 10.7 percent higher price than the 72 reed cloth in the rest of his series. 


\section{References}

Aikin, John, Description of the Country from Thirty to Forty Miles around Manchester (Manchester, 1795).

Anderson, Adam, An Historical and Chronological Deduction of the Origin of Commerce,... (London, 1801).

Ashton, T. S., 'Some statistics of the Industrial Revolution', Manchester School (May 1948).

Baines, Edward, Jr., History of the Cotton Manufacture of Great Britain (London, 1835).

Beverbrook, W. H., Prices and wages in England from the twelfth to the nineteenth century (Oxford, 1939).

Bythell, Duncan, The Handloom Weavers: A Study in the English Cotton Industry during the Industrial Revolution (Cambridge, 1969).

Crouzet, François, L'Economie Britannique et le Blocus Continental (Paris, 1958).

Cuenca Esteban, Javier, 'British textile prices, 1770-1831: are British growth rates worth revising once again?', Economic History Review, 2nd. series, XIVII (Feb. 1994), pp. 66-105.

Chapman, S. D. and S. Chassagne, European textile printers in the eighteenth century: a study of Peel and Oberkampf (1981).

Durie, Alastair J., 'Textile Finishing in the North East of Scotland, 1727-1860', in John Butt and Kenneth Ponting, eds., Scottish Textile History (Aberdeen, 1987), pp. 1-18.

Edwards, Michael M., The Growth of the British Cotton Trade, 1780-1815 (New York, 1967).

Fitton, R. S., The Arkwrights, Spinners of fortune (Manchester, 1989).

Huberman, Michael, 'How Did Labor Markets Work in Lancashire? More Evidence on Prices and Quantities in Cotton Spinning, 1822-1852,' Explorations in Economic History, 28 (Jan. 1991), pp. 87-120.

Lee, C. H., A cotton enterprise, 1795-1840: a history of M'Connel \& Kennedy, fine cotton spinners (Manchester, 1972).

Lyons, John S., 'The Lancashire Cotton Industry and the Introduction of the Powerloom, 18151850', unpublished Ph. D. dissertation, University of California, Berkeley, 1977. 
Montgomery, Florence M., 'John Holker's mid-eighteenth-century Livre d'Echantillons', in Veronika Gervers, ed., Studies in Textile History: In Memory of Harold B. Burnham (Toronto, 1977).

Neild, (William), 'An Account of the Prices of Printing Cloth and Upland Cotton, from 1812 to 186, \&c.', Journal of the Statistical Society XXIV (1861), pp.491-97.

O'Brien, Patrick, K., Trevor Griffiths, and Philip A. Hunt, 'Political Components of the Industrial Revolution: Parliament and the English Cotton Textile Industry, 1660-1820', Economic History Review, 2nd. series 44 (Aug. 1991), pp. 395-423.

Radcliffe, William, The Origin of the New System of Manufacture Commonly called Powerloom Weaving... (Stockport, 1828, reprinted Clifton, N.J., 1974).

Rothstein, Natalie, Barbara Rothstein's Album (London, 1987).

Ure, Alexander, The Cotton Manufacture of Great Britain, 2nd. edition with supplement by P. L. Simmonds, 2 volumes (London, 1861)

von Tunzelmann, G. N., Steam Power and British Industrialization to 1860 (Oxford, 1978).

Wadsworth, Alfred P. and Julia de Lacy Mann, The Cotton Trade and Industrial Lancashire, 1600-1780 (Manchester, 1931).

Young, Arthur, A six months tour through the north of England (London, 1770).

\section{Official Publications}

Report of the Select Committee on the Duties on Printed Cotton Goods, Parliamentary Papers 1818.

Returns Relating to Cotton, Parliamentary Papers 1819 XVI, pp. 96-121; 1828 XIX, pp. 286310.

Report of the Factory Commissioners, Parliamentary Papers 1834, IX.

\section{Manuscript Sources}

British Museum, Add.Ms. 38,376.

Cardwell, Birley and Hornby manuscripts, the John Ryland Library, Manchester, English Ms. 1199.

Oldknow Manuscripts, the John Ryland Library, Manchester, English Ms. 751-840. 
Sample Books, Winterthur Museum, Wilmington, Del., Ms. 65 x 698-700; 77 x 110.

The Wister Family Order Books, Winterthur Museum, Wilmington, Del., Ms. 56 x 10 . 
Figure 1

Yarn Prices, low and medium counts, 1768-1827

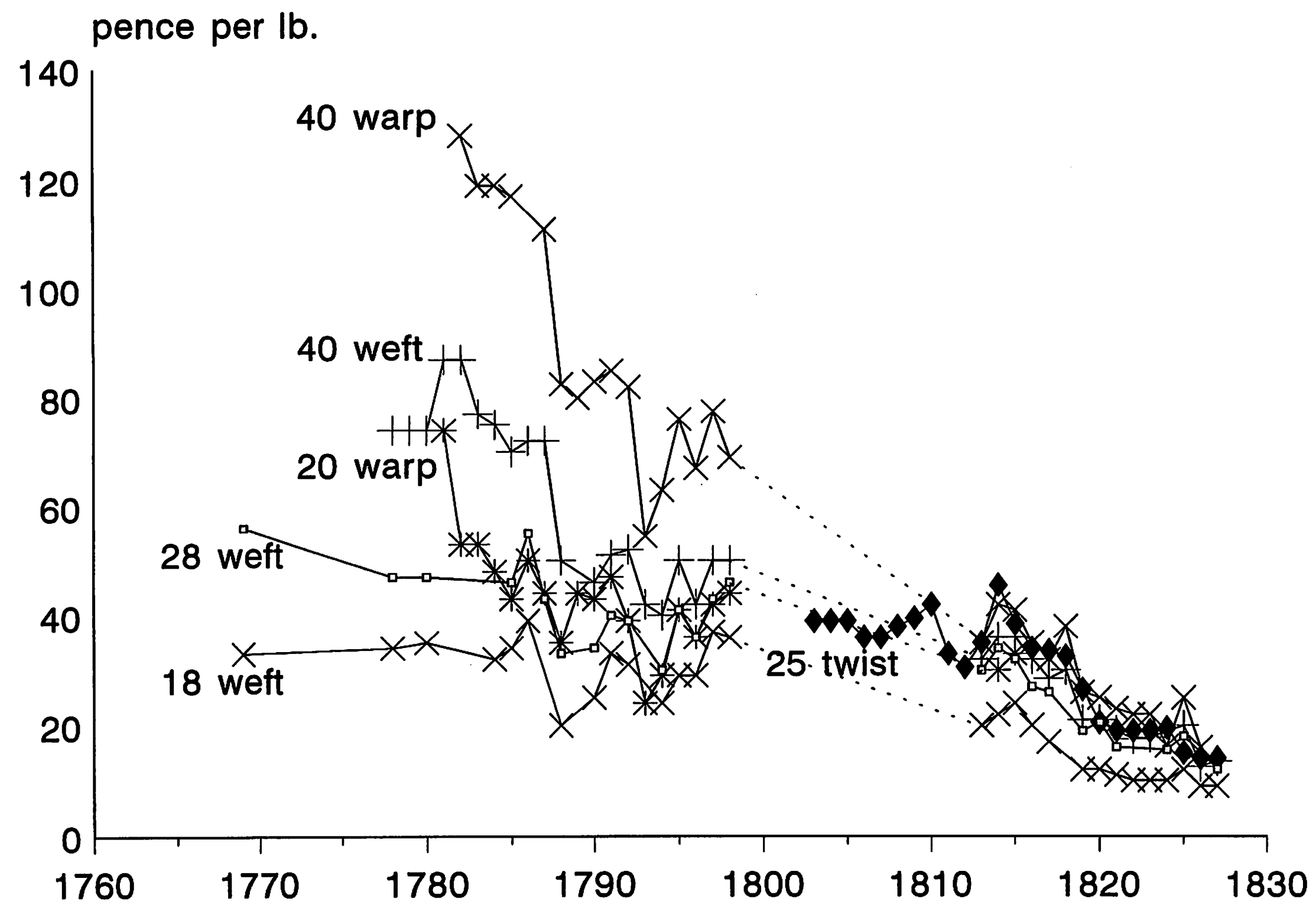


Figure 2

\section{Yarn Prices, Oldknow Inventory, 1783}

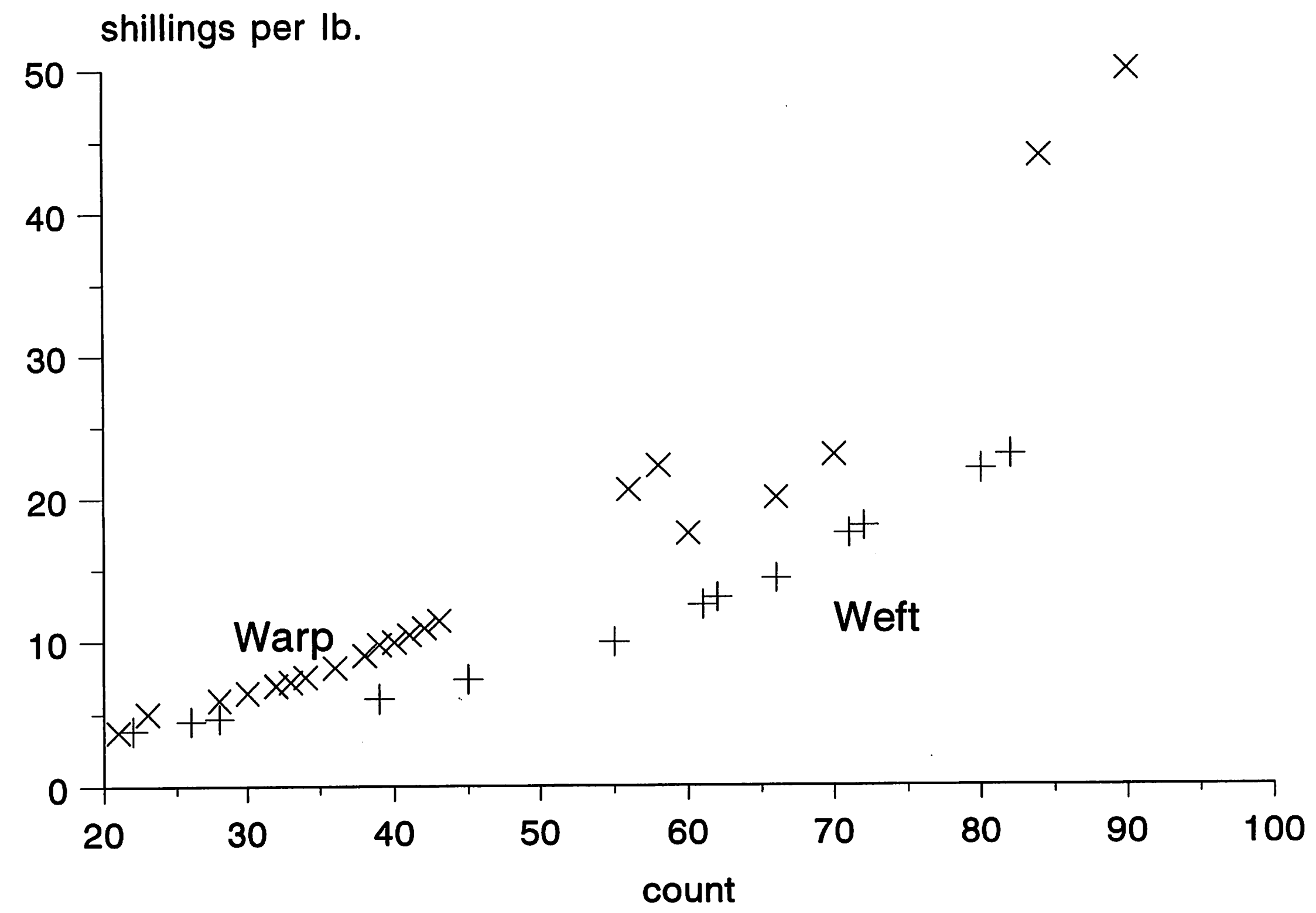




\section{Figure 3}

Yarn Prices, low and high counts, 1768-1827

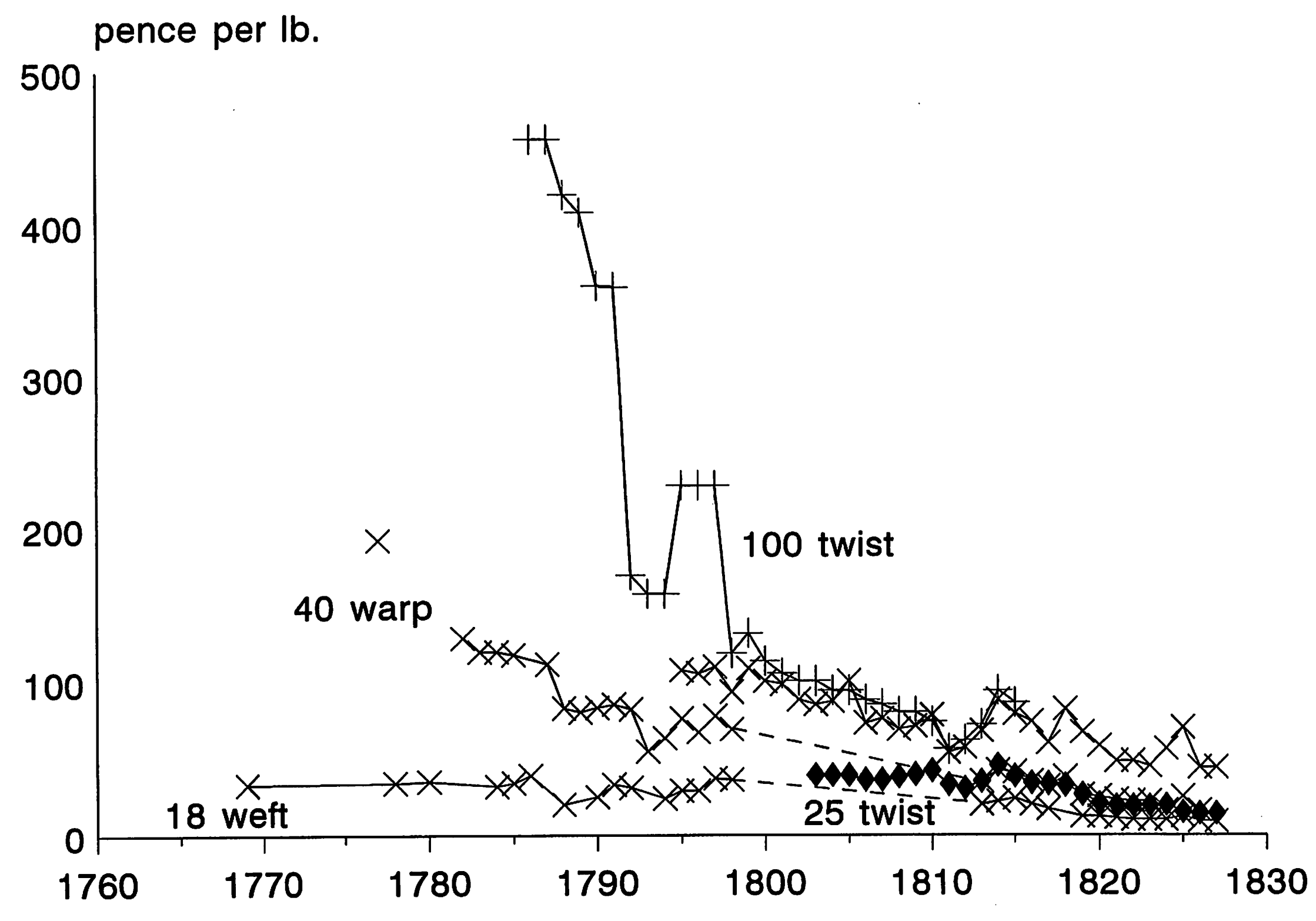


Figure 4

Cloth Prices, 1768-1827

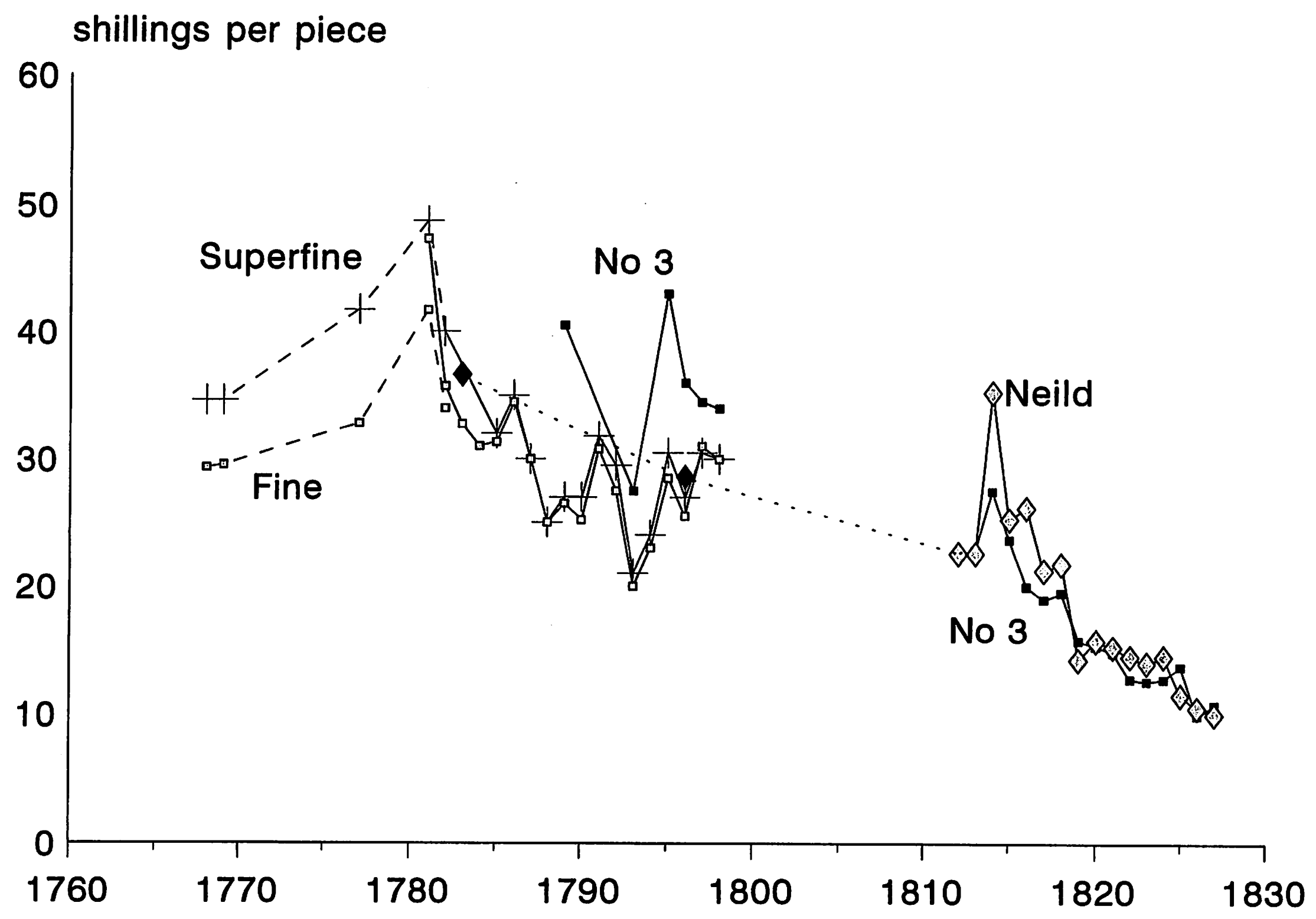


Figure 5

East India Company and British Cloth Prices, 1765-1830

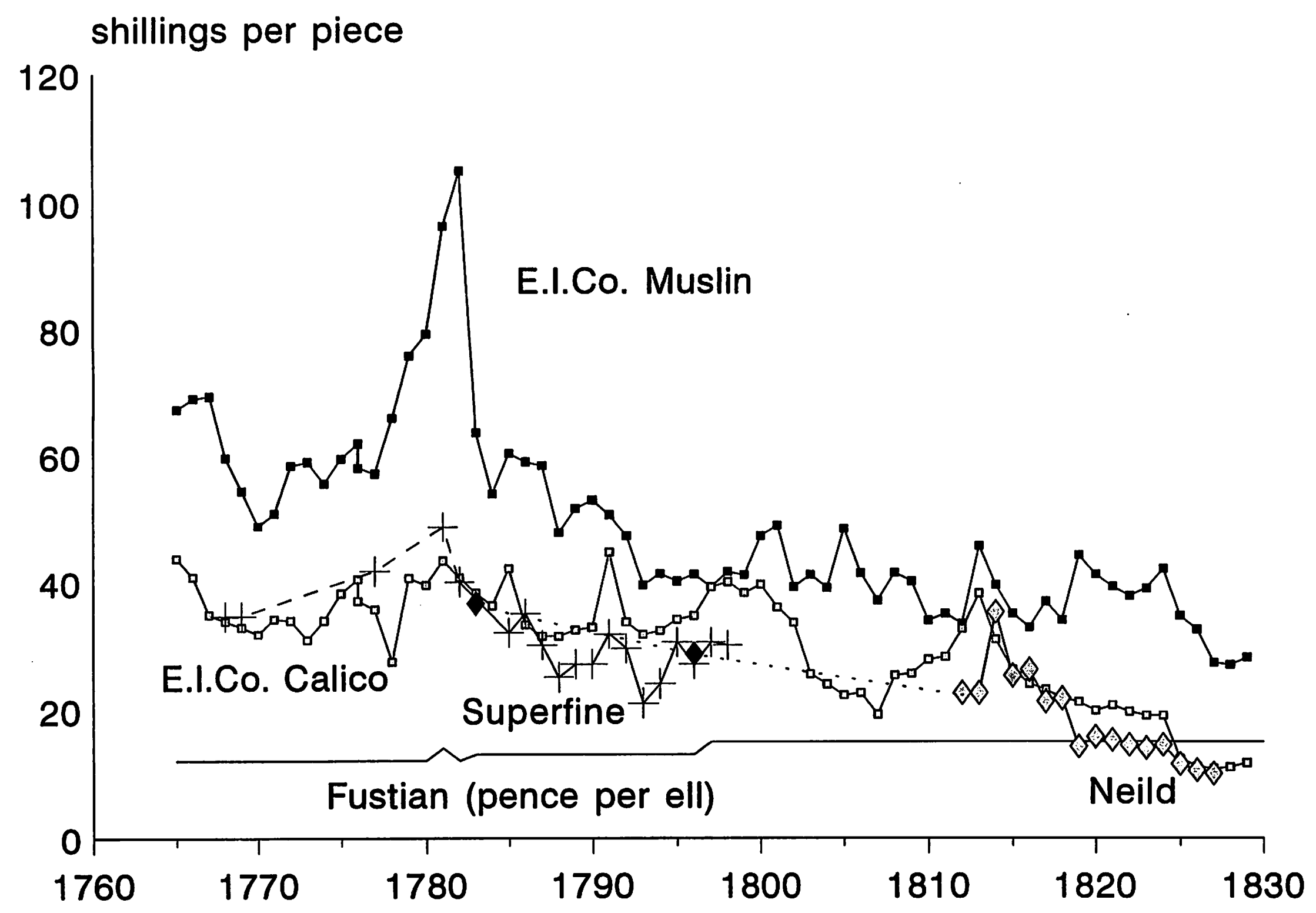

